\title{
Medicolegal
}

\section{Jury dismissed in the Dr Gee case}

\author{
CLARE DYER
}

The libel action by Dr Sidney Gee against the BBC and two other doctors (17 November, p 1086, and 24 November, p 1460) took a singular and dramatic turn last week when after three days of legal argument the judge, Lord Justice Croom-Johnson, discharged the jury and announced that he would try the case alone. Senior libel lawyers said they knew of no precedent where a judge had discharged a jury without the consent of all parties during a trial and proceeded to try the case himself.

The decision came after the BBC's counsel, Andrew Rankin QC, questioned Dr Gee about a document in French containing a reference to a Dr Gee as performing abortions in Victoria Street, Rochester. Dr Gee denied that he had ever seen the document and insisted that he knew nothing about it. Despite interventions by the judge, pointing out that the document was inadmissible as evidence, counsel persisted with a further question: "Does that document not advertise that $\mathrm{Dr}$ Gee, with the address in Rochester, will perform an abortion up to four and a half months for 2000 francs?"

The judge said that the cross examination was improper and prejudicial. It was represented to the jury that the document was a leaflet, when it was a photocopy of pages from a book; that it was an advertisement by Dr Gee, when it was not; and that it was a contemporary document, whereas from internal evidence it could not be dated as later than 1973, or perhaps 1974. Lastly, he said, it was not made clear that the document referred not only to $\mathrm{Dr}$ Gee's premises but also to other premises in England and other parts of Europe where abortions might be carried out.

Dr Gee's counsel, Michael Beloff QC, applied for the jury to be discharged, contending that the cross examination had prejudiced his client's chances of a fair trial and that the abortion issue was not relevant. Mr Beloff suggested that rather than empanel a new jury and throw away all the costs already incurred the judge should try the case alone.

For the defendants, $\mathrm{Mr}$ Rankin submitted that his cross examination was relevant to the case. It was based on contradictions in Dr Gee's evidence about the activities of his wife, Dr Elman, and her availability to provide cover for her husband. It was also concerned with how much time he was able to give to his obese patients, and it was only a tiny part of what promised to be a very long case. Rather than discharge the jury, counsel suggested, a disclaimer could be brought to their attention, putting right the wrong impressions created during the cross examination.

Lord Justice Croom-Johnson conceded that if a satisfactory disclaimer were put immediately before the jury and supported by a clear direction in the summing up the cross examination might not by itself have justified discharging the jury. But, he continued, he had come more and more to wonder whether this case was any

London NW

CLARE DYER, BA, BLS, solicitor and legal journalist longer suitable for trial by jury. The issues were constantly growing.

The rules on trial by jury in civil cases lay down that a libel action will be tried by a jury if any party asks for it unless the court believes that the trial requires "any prolonged examination of documents or accounts, or any scientific or local investigations which cannot conveniently be made with a jury." (In practice, libel cases are almost always tried by jury. In this case, the order for a jury trial had been made at Dr Gee's request.) The rules also say that an order laying down the mode of trial "may be varied by a subsequent order of the court made at or before trial."

In deciding whether he had the power, without the consent of all the parties and several weeks into the trial, to undo an order for jury trial made before the trial began, his lordship referred to a 1931 case in which the Court of Appeal had held that a trial judge could alter an order directing that the case should be tried by a jury without an application from either party and against the parties' wishes. In that case the order removing the case from the jury was made before the trial had begun. But, said his lordship, the words "at trial" used in the current rule were wide words capable of covering any time from the moment when the case was called on to the moment when it became apparent that the case ought not to be tried by a jury.

His lordship summarised the main issues in the case. Firstly, did Dr Gee prescribe dangerous drugs in such quantities and in such circumstances as to put the patients' lives at risk or their health in danger? Secondly, did he fail in a duty, which the defendants said was placed on him, to make inquiries from the patients' other doctors as to their medical history or as to any other treatment which was being given to them? Thirdly, did he fail, by being in breach of medical etiquette, by treating these patients without having letters of referral to him from doctors on whose lists they were or might have been? Fourthly, was Dr Gee therefore unfit to be a registered medical practitioner?

Lord Justice Croom-Johnson said there were over 900 pages of medical articles and papers to be referred to and many expert witnesses to be called for both sides. Between all these the jury would have to balance the probabilities, assuming they could understand what was being said and the technical words already used-about which he had considerable doubt. In addition, there was the problem of construing medical etiquette.

Adding the risk of prejudice from the questions about the abortion practice to the number of documents and the need to consider complicated medical evidence, the judge concluded that he should try the case alone.

Though the BBC and Dr Mitchell and Dr Blackwood, the two doctors sued by Dr Gee, would have preferred the case to continue with the jury, they decided not to appeal against the judge's ruling. At least they have been spared the wasted legal costs-estimated as $£ 100000$ for the BBC and a total of $£ 65000$ for the two doctors-which empanelling a new jury would have meant. With the interruptions in the evidence caused by the legal arguments and by the earlier illness of the judge and one of the jurors, the case is likely to run well into January and cost more than $£ 500000$. 